\title{
Ethnic Language and Bilingualism: The Acquisition of Karajá as a Second Language
}

\author{
Caroline Pereira de Oliveira $^{1}$ \\ Rogério Vicente Ferreira ${ }^{2}$ \\ Curso de Letras e Licenciatura Intercultural, Universidade Federal de Mato Grosso do Sul, \\ Aquidauana, MS, Brasil \\ Vanessa Hagemeyer Burgo ${ }^{3}$ \\ Curso de Letras, Universidade Federal de Mato Grosso do Sul, Três Lagoas, MS, Brasil
}

\begin{abstract}
This work aims to discuss the acquisition process of ethnic language as a second language in the community of Buridina in Aruanã - Goiás - Brazil. By drawing attention to bilingualism, we observe the practice of alternately using two languages: some people speak Portuguese as their first language while others speak Karajá. We also intend to highlight the actions promoted by Karajá people in order to preserve their own language, culture, values, tradition and knowledge, bearing in mind their need to interact with nonindigenous people within an indigenous society whose predominant language is Portuguese for many inhabitants. Our theoretical framework is based on studies concerning bilingualism and second language acquisition related to indigenous studies. According to the findings, the acquisition of Karajá as a second language, in Buridina, occurs both in social specialized spaces as well as in social daily life contexts, comprising activities that value cultural and intercultural aspects of that community's language.
\end{abstract}

Keywords: Ethnic language; Bilingualism; Karajá; Second language acquisition.

Título: Língua étnica e bilinguismo: a aquisição do Karajá como segunda língua

Resumo: Este artigo visa a discutir o processo de aquisição de língua étnica como segunda língua na comunidade de Buridina em Aruanã-Goiás-Brasil, observando a realidade do bilinguismo, uma vez que há a prática alternada do uso de duas línguas: alguns têm como primeira língua o português, e outros, o Karajá. Pretendemos assinalar, também, as ações promovidas pelo povo Karajá para a preservação de sua própria língua, cultura, valores, tradição e conhecimentos, frente às necessidades de interação com os não índios nesta sociedade indígena cuja língua predominante é, para muitos, a língua portuguesa. 0 arcabouço teórico está embasado nos estudos concernentes ao bilinguismo e à aquisição e aprendizagem de segunda língua direcionados aos estudos indígenas. Conforme os resultados, a aquisição do Karajá como segunda língua, em Buridina, ocorre tanto em

\footnotetext{
1 Mestre em Linguística (Universidade Federal de Goiás). Docente do curso de Letras na UFMS. Orcid: http://orcid.org/0000-0002-3161-4078. E-mail: caroline.p.oliveira@ufms.br.

2 Doutor em Linguística (Universidade Estadual de Campinas). Docente do curso de Letras e do Programa de Pós-Graduação Estudos de Linguagens na UFMS. Orcid: https://orcid.org/0000-0002-4308-6735. E-mail: rogerio.v.ferreira@ufms.br.

${ }^{3}$ Doutora em Estudos da Linguagem (Universidade Estadual de Londrina). Docente do curso de Letras e do Programa de Pós-Graduação em Letras na UFMS. Orcid: https://orcid.org/0000-0001-5350-6943. E-mail: vanessahburgo@hotmail.com.
} 
espaços sociais especializados, quanto em contextos sociais da vida cotidiana, compreendendo atividades que valorizam aspectos culturais e interculturais da língua dessa comunidade.

Palavras-chave: Língua étnica; Bilinguismo; Karajá; Aquisição de segunda língua.

\section{Introduction}

Bilingualism and Second Language Acquisition are frequent issues among language scholars. However, they are mostly present in works which deal with so-called "prestigious" or "dominant" languages whereas only few studies address the situation of bilingualism in minority societies. We claim that the Karajá people's language, Iny Rybè ${ }^{4}$, is an ethnic language due its nature of being a cultural entity of this people, defined on the grounds of being identified with the people and their language. Besides signifying an ethnicity, a linguistic group, Iny Rybè also reflects fighting and strength to maintain such identification, since the sociodiscursive spaces of this community have changed in such a way that the language has lost its place during daily and specialized activities in the indigenous community of Buridina, Aruanã - Goiás - Brazil.

The community of Buridina is reported, according to Portela (2006), as one of the oldest of the Karajá people. Based on Krause (1943 apud PORTELA, 2006), the village Buridina has been located at the confluence of the rivers Vermelho and Araguaia since the beginning of the 20th century. On an expedition to Araguaia in 1908, this ethnologist produced a report for the Leipzig Museum of Ethnology in which he describes the trip that started in Leopoldina, now Aruanã, and states that the foundation of the Karajá village, in Aruanã - Goiás - Brazil, took place around 1903.

Accordingly, both the residents of Aruanã and the indigenous report that even before the 19th century, the Karajá migrated from Ilha do Bananal to collect "taquari", a type of vegetable used for handicrafts. They also say that the village was located, since the end of the 19th century, slightly below its current location, that is, on the banks of the Red River, and that their definitive settlement to the present site happened in 1914 (period when the first information about the Karajá settlement was provided). This is the place where they have been living since Captain Pedro Dantas met the Karajá people when he arrived in Leopoldina (PORTELA, 2006).

The constitution of Aldeia Buridina refers to a characteristic feature of Karajá culture: the creation of new local groups and descendants. The following map shows the current organization of Buridina, including the arrangement of houses, schools, football fields etc.

\footnotetext{
${ }^{4}$ Iny Rybè means Karajá language in Karajá.
} 
Figure 1 - Arrangement of houses in Aldeia Buridina

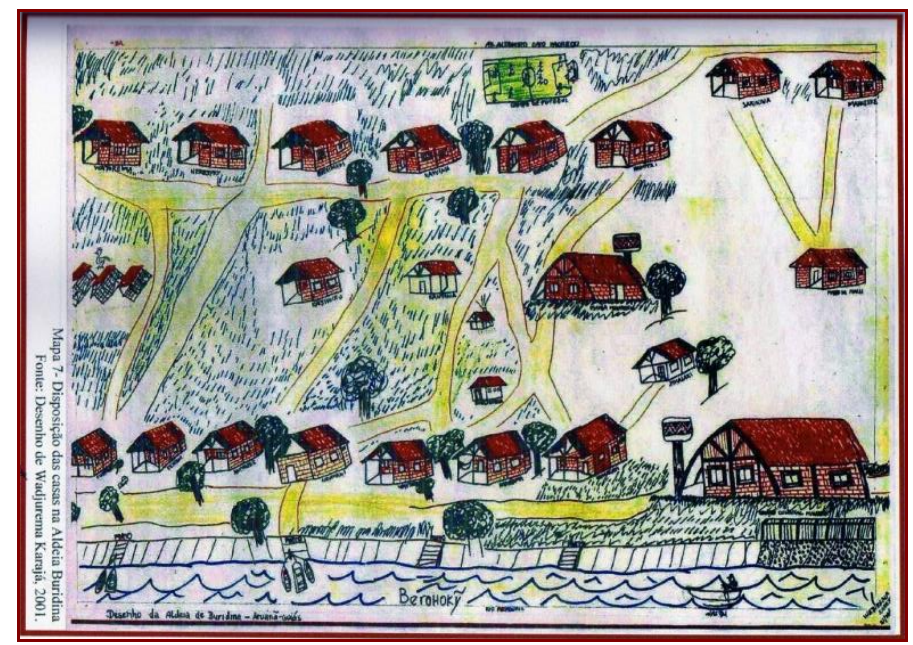

Source: Oliveira (2007, p. 7).

The Karajá people have lived in direct contact with non-indigenous society since the period of Brazilian hinterland colonization and, since then, they have been living in conflict between the maintenance of their tradition and the adoption of nonindigenous/communities' new way of life. Artistic productions, such as handicrafts, drawings, the narration of myths and traditional festivals promote, in a unique way, the rapprochement of the community, as a whole, with its own values and activities as constituting Karajá people. These traditional activities, and due to the use of the language connected to them, are understood as specialized spaces for the Karajá language usage, which are different from the everyday spaces composed by the speeches of family, circles of friends, and informal conversation in general (PIMENTEL DA SILVA, 2001).

\section{Methodology}

The methodological approach used for data collection of this paper was developed in the Maurehi Indigenous Education and Culture Project (PIMENTEL DA SILVA, 1994) in the community of Buridina-GO-Brazil. In that project, researchers have been developing reports, analysing teaching material (PIMENTEL DA SILVA, 2007; OLIVEIRA; PIMENTEL DA SILVA, 2011) as well as conducting a survey of documentation regarding the Karajá people's education system in Buridina-Go-Brazil at the State Secretariat for Education of the State of Goiás-SEDUC-GO-Brazil.

That project influenced the creation of the Maurehi Indigenous State School which promotes activities to strengthen the use of the Karajá language both within the family and in working relationships involving the entire community (PIMENTEL DA SILVA, 2001). The process of acquiring Karajá as a second language at school is, therefore, cultural, and intercultural, as it promotes interaction among students, teachers and all those involved in that activity within the socio-cultural reality of Buridina. 
By means of the above-mentioned project, it was possible to have conversations with people from Buridina and with other Karajá residents in other villages. During those conversations, we realized that the mother tongue acquisition, and the defence of people's language and tradition is yet another form of resistance against the dominant society, which means a restoration of both its culture and the maintenance of Buridina as a Karajá village.

We now proceed to theoretical discussions on the distinction between second language acquisition and second language learning.

\section{Second Language Acquisition and Second Language Learning}

Concerning second language acquisition, Krashen (2002[1981]) states that the acquisition of a second language is similar to the way children acquire their mother tongue. In L2 acquisition, learners are not always aware of grammar rules, but they know that they are using language for communication. As the scholar points out, language acquisition "requires meaningful interaction in the target language--natural communication--in which speakers are concerned not with the form of their utterances but with the messages they are conveying and understanding" (p. 1).

On the one hand "acquirers need not have a conscious awareness of the 'rules' they possess, and may self-correct only on the basis of a 'feel' for grammaticality" in language acquisition, on the other hand, it is a conscious process in which explicit rules are assimilated and observed in less natural environments, such as the classroom. Language acquisition is a natural process of assimilation; it is the product of real interaction among people in which the learner is an active participant. Language learning is mostly helped by error correction and explicit rules. "Error correction it is maintained, helps the learner come to the correct mental representation of the linguistic generalization" (KRASHEN, 2002[1981], p. 2).

Schütz (2007) claims that the acquisition approach values the communicative act and ends up promoting the development of self-confidence in the learner. This author presents a classic example of second language acquisition involving teenagers and young adults who either live outside their birth country or inside a community whose language is different from their own, but who, in most cases, however, manage to achieve fluency in the target language when at least a little bit of it is known by them.

Klein (1986) relates this view of language acquisition to its spontaneous form of acquisition. He argues that there is a social difference in the process of language acquisition that occurs in both a spontaneous and a guided way: spontaneous learning and guided language learning, respectively. The former develops in the social environment in which the language is spoken, free from systematic and intentional intervention by a tutor ${ }^{5}$. It is acquired through social and interactive relationships immersed in the target language

\footnotetext{
${ }^{5}$ The tutor is the one who, when interacting linguistically with others in the process of acquisition, interrupts them during their speech in order to highlight some structural aspects that may not have been properly presented.
} 
society. Language acquisition does not occur by means of a logical and regular sequence of linguistic structures, but in everyday communication, which presents, at a first glance, a very interesting paradox: learners need to learn the language to communicate, and they need to communicate to learn the language at the same time.

This type of language acquisition is often related to contact among people of different languages in border regions, where communication occurs due to the need for interaction with others, who are speakers of other languages. This is the reality at the Brazilian borders with the Spanish American countries; Brazilian indigenous communities since their first contacts with the Portuguese language; indigenous communities that live today in a multilingual context, such as the Xingu Indigenous Park. As claimed by Seki (1993), seventeen peoples who speak different languages are present in this region: Suyá, Tapayuna, Mentuktire, Panará, Waurá, Yawalapiti, Mehináku, Kuikuro, Kalapalo, Matypu/Nahukwa, Txikão and Trumai. In this situation, some learn the other's language spontaneously and use it to communicate with their neighbouring peers.

What draws most attention as regards the spontaneous second language acquisition process, during everyday communication, is the learners' lack of awareness of the language they are acquiring, as what matters to them is the fact that communication processes actually happen. As Klein (1986, p. 16) explains, "the spontaneous learner can avail himself of different means of communication at any point". According to the scholar:

The spontaneous learner takes a different attitude to the means of verbal communication than is customary in a language teaching setting. At the same time, there is little need or opportunity for metalinguistic reflection: little if any thought is given to linguistic forms and rules, which are the domain of tutored language learning (KLEIN, 1986, p. 17).

As presented by Klein (1986), guided acquisition is opposed to spontaneous acquisition, since, in the latter, there is no "tutor" who chooses the sequence of linguistic knowledge to be acquired by apprentices through a methodological apparatus used in the classroom in order to make them formally acquire the structures of the target language, which comprise, in most cases, only writing and reading skills. The author analyses how systematization can influence the second language acquisition process in two ways:

a) The way in which the target language material is presented to the learner, as in this process, the learner comes into contact with guided acquisition that substantially differs from that presented in spontaneous acquisition, since we do not have a situation of social interaction in which the learner can extract linguistic rules from communication. This perspective focuses on the form of the language being used rather than on its communicative intent, for instance: the explanation of linguistic rules. The presentation selection and order of the material to be used will depend on the degree of difficulty and the students' linguistic level, and, as mentioned by Ellis (1994, 1997, p. 45), teachers adapt their way of speaking according to the students' 
level of proficiency similarly to foreigner talk ("the language that native speakers use when addressing non-native speakers"). Therefore, learning the target language depends on what learners were exposed to in the classroom that can gradually grow in order to enable students to mentally process the knowledge acquired.

b) The opportunities offered for the application of the available linguistic repertoire in a formal situation, which is as complex as the spontaneous form of acquisition. On the one hand, in formal acquisition, learners' repertoire is quite limited, and they have "no choice but to lean heavily on discourse rules" (KLEIN, 1981, p. 131). On the other hand, in this situation, learners are able to employ, in most cases, the repertoire they acquired by means of the exercises proposed by the teacher through dictations, written and oral evaluations, and even when they are in a real interaction in the target language (KLEIN, 1981).

Baker (2001) points out two forms of bilingualism: additive and subtractive. Additive bilingualism occurs when second language acquisition does not represent an obstacle for the mother tongue, that is, the addition of a second language or culture may not replace the first language or culture. Learners can maintain both languages, even for an indefinite period or sometimes for their entire life. "For example, English-speaking North Americans who learn a second language (e.g. French, Spanish) will not lose their English but gain another language and some of its attendant culture" (p. 58). In contrast, subtractive bilingualism occurs when the second language and culture are acquired with pressure to replace the first language, which is usually a minority language. "For example, an immigrant may find pressure to use the dominant language and feel embarrassment in using the home language" (p. 58).

In Brazilian indigenous societies, according to Maher (1996), the phenomenon of bilingualism creates situations of the indigenous language vitalization, but, on the other hand, it also provides circumstances that lead to their death. Thus, in this situation, the Portuguese language invades the sociodiscursive spaces of the communities' daily lives, as it happened with the Karajá of Buridina, who had their language displaced from these contexts of use.

Another linguistic phenomenon that occurs in indigenous communities is called diglossia. Hamel (1988) explains that diglossia comes from the intercultural conflict, whose sociolinguistic aspects are manifested in an asymmetric relationship between dominant discursive practices (usually crystallized in the dominant language: in Brazil, the Portuguese language) and dominated discursive practices (mostly expressed in indigenous languages). Diglossia can also be part of the ideology of minority communities, and it ends up corroborating the process of subtractive bilingualism, as the use of the dominant language in communities with less linguistic prestige has been increasingly present in everyday life of these communities.

It is relevant to highlight the importance of keeping indigenous communities alert about their linguistic attitude at all times, which can be conceptualized, according to 
Córdova Gastiaburu (2006), as speakers' attitudes towards a language or a specific variety based on the belief or idea they may have of it and the use they can make of it in society.

\title{
Bilingualism: different motivations
}

Several factors contribute to the people or groups of people becoming bilingual, such as: migratory movements, marriage among different ethnicities, plurality of linguistic groups within the same region etc. Social, political, and historical circumstances, therefore, promote bilingualism (GROSJEAN, 2001).

Baker (2001) highlights that there are various routes to bilingualism and such routes include:

\begin{abstract}
learning two languages early on in the home; acquiring a second language in the street, in the wider community, in the nursery school, elementary or high school; and, after childhood, learning a second or foreign language by adult language classes and Courses. [...] a discussion of bilingualism has to take in psychological, linguistic, social and educational factors. [...] political factors are also crucial in understanding bilingualism and bilingual education. While psychologists and linguists have studied the development of children's two languages, it is important to examine simultaneously the social context in which children acquire their languages. Being a member of an immigrant community, an elite group, a counterelite, a majority or minority language group are important 'macro' influences in the acquisition of bilingualism. There are also 'micro' social contexts of the street, the nursery, the school, and the local community that similarly foster functional bilingualism. Such contexts tend to make bilingualism a constantly shifting rather than a stable phenomenon (BAKER, 2001, p. 86).
\end{abstract}

The scholar points out the major features of becoming bilingual via second language learning and six components are considered:

a) Linguistic input: it is the "type of second language information received when learning or acquiring a second language" (BAKER, 2001, p. 117). An example of this would be how teachers or native speakers adjust their language to the level of second language learners to make it understandable.

b) In meaningful input, language is essentially about conveying meaning: in the 1970s, the focus "has tended to shift partly away from teaching the formal nature of a language to socially appropriate forms of communication" (BAKER, 2001, p. 119).

Baker (2001) considers language as a means to an end, not the way around, and that we use a language for specific purposes. Language learning is not based on mere grammatical knowledge, but on the effective ability of communicating information.

c) When it comes to second language acquisition in a controlled way, in which the input occurs in the classroom, we must bear in mind some particularities of the environment in which it occurs, as well as in the performance of the teacher. The author also stresses that input does not guarantee second language acquisition since 
it occurs via external means. For instance, apart from presenting some vocabulary/structures to the student, the teacher also needs to promote intake ${ }^{6}$.

d) According to Krashen (2002 [1981]), acquisition is the result of comprehensible language input, and if the student understands that, the linguistic structures will consequently be acquired. The scholar affirms that second language acquisition is the result of the process of understanding second language input.

Baker (2001) states that it is essential that language teaching prepares learners/students for real situations of communication so they can feel sufficiently capable of and confident to deal, in the real world, with the second language structure, and thus to continue their acquisition process.

e) In agreement with the author, "given the same contexts and same inputs, students still gain different levels of proficiency in the second language" (BAKER, 2011, p. 121). He highlights some factors that can explain individual differences and their linguistic developments in relation to second language acquisition. Among them, we mention here ability and aptitude, attitude, and motivation. Thus, differences among individual learners include:

a. Ability and aptitude: ability has often been connected to formal classroom settings, and it is one of the reasons that would influence the rate of development in second language learning. "General ability may positively correlate with test scores on the formal aspects of language learning, (e.g. grammar, translation, parsing verbs)" (p. 122). Regarding the concept of aptitude:

An adult finding difficulty in learning a specific second language may place the blame on a lack of aptitude for language learning in general. This tends to indicate a belief that there is something in an individual's nature that cannot be nurtured. However, the concept of aptitude has recently come under attack. It is unclear how aptitude differs from general academic ability. If there is a difference between aptitude and general ability, it is unclear as to its constituent features. If we are unsure of its definition and structure, it is difficult to know precisely what is being tested in modern language aptitude tests. While aptitude may affect the speed of second language acquisition in the formal classroom environment, it would not seem to affect the sequence or order of second language acquisition. There is also no evidence to show that aptitude affects the route which people take in second language acquisition (BAKER, 2001, p. 122-123).

b. Attitudes and motivation: there is a connection between acquirers' attitude and motivation towards second language acquisition, and as Krashen (p. 21) notes, "attitudinal factors that relate to second language acquisition will be those that perform one or both of two functions": factors that encourage performers to communicate with speakers of the target language, consequently making them able to obtain the necessary input or intake for

\footnotetext{
${ }^{6}$ Intake refers to the inner assimilation of that second language (BAKER, 2001, p. 120).
} 
language acquisition; and factors that make performers able to use the language heard. "Simply hearing a second language with understanding appears to be necessary but is not sufficient for acquisition to take place. The acquirer must not only understand the input but must also, in a sense, be "open" to it" (p. 21).

f) The result of acquiring a second language also integrates the relation proposed by Baker (2001) as a basic component of becoming bilingual. Van Ek (1986, 1987, apud BAKER, 2001, p. 130) draws attention to six different factors involved in achieving language competence for communicative purposes, namely linguistic, sociolinguistic, discourse, strategic, social-cultural, and social competence.

Chart 1: Factors involved in achieving language competence

\begin{tabular}{|c|c|c|c|c|c|}
\hline $\begin{array}{l}\text { Linguistic } \\
\text { competence }\end{array}$ & $\begin{array}{l}\text { Sociolinguistic } \\
\text { competence }\end{array}$ & $\begin{array}{l}\text { Discourse } \\
\text { competence }\end{array}$ & $\begin{array}{l}\text { Strategic } \\
\text { competence }\end{array}$ & $\begin{array}{l}\text { Sociocultural } \\
\text { competence }\end{array}$ & $\begin{array}{l}\text { Social } \\
\text { competence }\end{array}$ \\
\hline $\begin{array}{l}\text { Language can } \\
\text { be decomposed } \\
\text { into its } \\
\text { linguistic } \\
\text { constituents } \\
\text { (e.g. grammar, } \\
\text { vocabulary). }\end{array}$ & $\begin{array}{l}\text { It concerns the } \\
\text { ability to } \\
\text { communicate } \\
\text { accurately in } \\
\text { different contexts, } \\
\text { with different } \\
\text { people, and when } \\
\text { there are } \\
\text { different } \\
\text { intentions in the } \\
\text { communication. } \\
\text { Sociolinguistic } \\
\text { competence is } \\
\text { the awareness of } \\
\text { the language form } \\
\text { required in } \\
\text { different } \\
\text { situations. Such } \\
\text { competence } \\
\text { arises } \\
\text { natural interaction occurs } \\
\text { between } \\
\text { students, without } \\
\text { prompting } \\
\text { by the teacher. }\end{array}$ & $\begin{array}{l}\text { It is the ability to } \\
\text { use appropriate } \\
\text { strategies in } \\
\text { constructing and } \\
\text { interpreting } \\
\text { different texts, the } \\
\text { ability to } \\
\text { contribute to the } \\
\text { construction of a } \\
\text { spoken discourse } \\
\text { in communication. } \\
\text { For example, } \\
\text { discourse } \\
\text { competence is } \\
\text { found in the ability } \\
\text { to use pronouns, } \\
\text { transition words } \\
\text { and insert } \\
\text { progression into } \\
\text { communication. }\end{array}$ & $\begin{array}{l}\text { It is the ability to } \\
\text { use verbal and } \\
\text { non-verbal } \\
\text { communication } \\
\text { strategies to } \\
\text { compensate for } \\
\text { gaps in the } \\
\text { language user's } \\
\text { knowledge. } \\
\text { Strategic } \\
\text { competence } \\
\text { concerns the } \\
\text { ability to use body } \\
\text { language } \\
\text { (gesturing, head } \\
\text { nods, eye contact) } \\
\text { to } \\
\text { give meaning } \\
\text { when verbal } \\
\text { language is not at } \\
\text { a level of } \\
\text { competence to } \\
\text { convey } \\
\text { meaning. }\end{array}$ & $\begin{array}{l}\text { It is the } \\
\text { 'awareness of the } \\
\text { sociocultural } \\
\text { context in } \\
\text { which the } \\
\text { language } \\
\text { concerned is used } \\
\text { by native speakers } \\
\text { and the ways in } \\
\text { which this } \\
\text { context affects } \\
\text { the choice and } \\
\text { the } \\
\text { communicative } \\
\text { effect } \\
\text { particular } \\
\text { language forms' }\end{array}$ & $\begin{array}{l}\text { It is the ability to } \\
\text { use particular } \\
\text { social } \\
\text { strategies to } \\
\text { achieve } \\
\text { communicative } \\
\text { goals. For } \\
\text { example, social } \\
\text { competence } \\
\text { includes } \\
\text { the ability to } \\
\text { take the } \\
\text { initiative in a } \\
\text { conversation, to } \\
\text { know when to } \\
\text { interrupt } \\
\text { someone } \\
\text { else speaking } \\
\text { without being ill- } \\
\text { mannered. } \\
\text { Social } \\
\text { competence } \\
\text { involves } \\
\text { understanding } \\
\text { the } \\
\text { conventions that } \\
\text { govern } \\
\text { communication } \\
\text { within a culture. }\end{array}$ \\
\hline
\end{tabular}

Source: Van Ek (1987, apud BAKER, 2001, p. 39-40, 130).

As Baker states (2001), there are several purposes that explain the reasons why children and adults acquire a second or third language, which are: 1) ideological reasons; 2) 
international reasons and 3) individual reasons. Pimentel da Silva (2001) adds one more purpose: 4) reasons for maintaining languages.

\section{Ideological reasons}

For children who belong to minority linguistic groups, the purpose of second instruction can be assimilationist and subtractive, for instance, the teaching of English as a second language, both in the United States of America and in England, aims at the rapid social integration of minority language groups in the societies in which they are inserted (BAKER, 2001).

In Brazil, the assimilationist indigenous policy was responsible for the disappearance of many indigenous languages. The Federal Constitution of 1988 ended the integrationist regime, as it established that:

indigenous people and their social organization are recognized, as well as their customs, languages, beliefs and traditions, and the original rights to the lands traditionally occupied by them, and it is incumbent on the Federal Government to demarcate them, protect and cause all their property to be respected (BRASIL, 1988, article 231).

This article not only grants the right to preserve indigenous languages, but also recognizes those languages as essential to their peoples.

Grosjean (2001) demonstrates that about half of the world population is bilingual, and thus bilingualism is present in every country of the world. Despite it, as Romaine (1995, p. 8-9) claims, monolingualism still "represents the norm, monolingualism is the basis for linguistic studies". In Brazil, for example, there is dominant monolingualism, and it portrays the power of a language over those considered minority. In fact, the author argues that monolingualism should be treated as a special case since it is the deviation from the norm, and bilingualism should represent the norm. He outlines that "there are about thirty times more languages than countries. It implies the presence of bilingualism in practically every country in the world".

\section{International reasons}

The international reasons that determine the importance of second languages acquisition are based on the need to negotiate and to understand the culture of other people. Language skills can open doors to economic activities and international trade. According to Baker (2001):

Second and third language learning is often encouraged for economic and trade reasons (e.g. in Singapore, Basque Country, Finland). Given notions such as common markets, open access to trade, the free market economy, the importance of international trade to developing nations, then facility with languages is seen as 
opening doors to economic activity. Selling to the Japanese, for example, may be almost impossible through English or German. Speaking Japanese and having a sympathetic understanding of Japanese culture, manners, values and thinking may be the essential foundation for economic activity (BAKER, 2001, p. 111).

\section{Individual reasons}

The above-mentioned author states that the individual reasons can be divided into four different reasons which explain why children or adults should learn or acquire a second language. The first reason is based on cultural awareness and sensitivity, and awareness can break down national, ethnic, or linguistic stereotypes. The second reason is cognitive development since the acquisition of a second or third language is seen as a way of sharpening the mind and developing the human intellect. The third reason involves affection goals: social, emotional, and moral development, self-awareness, self-confidence, and social and ethical values. And finally, the fourth reason is related to careers and employment. Being bilingual or multilingual can open up a variety of possibilities of careers such as: translators and interpreters, buyers and sellers of goods/ services or any kind of business activity involving local, regional, national and international companies. They can also migrate across national frontiers to find better jobs and, by means of technology, work from home or from the local village interacting with people from all over the world.

\section{Reasons for maintaining languages}

When the second language to be acquired by children is a minority or ethnic language, the aim of second language acquisition is to maintain and preserve language and culture as a way to rescue cultural values embedded in their language. We highlight some examples of this situation: the teaching of the Maori language as a second language in New Zealand (Baker, 2001), which aims to preserve and strengthen indigenous bonds and values; it also occurs with the teaching of Karajá language in the community of Buridina, located in the municipality of Aruanã - Goiás. In this community, actions have been developed for ten years in order to maintain Karajás' contact with their native language ${ }^{7}$. These actions happen spontaneously, in contact with speakers of this language from other villages, and in the reconstruction of the socio-discursive spheres of Karajá language usages, in a more formal way (at school) and an informal way (during the narration of the traditional myths of this culture) (PIMENTEL DA SILVA, 2001).

\footnotetext{
7 The term 'heritage language' may also be called 'native language', 'ethnic language', 'minority language', 'ancestral language', aboriginal language, or, in French, 'langues d'origine'. The danger of the term 'heritage' is that it points to the past and not to the future, to traditions rather than the contemporary. Partly for this reason, the UK term tends to be 'community language' or 'where English is an additional language'. The heritage language may or may not be an indigenous language. Both Navajo and Spanish can be perceived as heritage languages in the USA depending on an individual's perception of what constitutes their heritage language (BAKER, 2001, p. 209).
} 
In the process of revitalizing and invigorating threatened languages, it is important to have a conception of language that considers its context of production, the place of culture, and the human activities involved in this process to provide the resumption of values as well as the use of language in a functional way.

\section{Sociolinguistic Situation of Buridina}

Intercultural awareness has mainly been considered in the teaching of ethnic language as a second language. In this context, it is very important to know the sociolinguistic situation of the community involved. Therefore, we present below the sociolinguistic situation of Buridina, the place where our study was carried out.

Currently, the Karajá population in Buridina is made up of approximately 200 people, who reside in two villages demarcated by the government within the city of Aruanã. The increase in population was due to two main factors. Firstly, quality of life has been increasing as these indigenous people have been specializing as artisans of Karajá art, which can provide them with a profession and, consequently, an income; and secondly, people who lived and worked on nearby farms and also those who lived in other villages have returned to Buridina.

Many people who live in Buridina have Portuguese as their first language; others, Karajá. In general, children have contact with both languages. The greater or lesser contact with Portuguese or Karajá language varies according to their mother's language because this is the language that the child has spent more time on.

The implementation of the Maurehi Indigenous Education and Culture Project has changed the community's sociolinguistic framework. Nowadays, indigenous people increasingly aim to use the Karajá language (PIMENTEL DA SILVA, 2001). Most young people have become receptively bilingual, that is, they do not speak Karajá, but understand it. They thus have a responsive attitude towards that language. This situation is observed when young people coherently respond in Portuguese to what was said in Karajá.

There is the Maurehi Indigenous State School within this community, which is also the result of the aforementioned project, and in which all activities are guided by the principle to value all uses of the Karajá language in an attempt to reconstruct the social spaces in which it has been used in Buridina. The aim of these activities is to enable Buridina's children and young people to appropriate Karajá knowledge and, in this context, they take part, together with elders, in the reconstruction of social spaces for cultural production in their village. Some of these spaces, by the way, have already been reconstituted. 


\section{Acquisition of indigenous language - some particularities}

The classic education process for the Karajá language acquisition in Buridina is connected to the traditional socio-discursive spaces of the Karajá culture. We illustrate these spaces using the graphic found in Pimentel da Silva (2001), which was based on the formal and informal spaces of Karajá language usage in the village of Santa Isabel do Morro, located on Bananal Island-Tocantins-Brazil. We used this study as a reference in the reconstruction of social spheres in Buridina.

Sociodiscursive spaces should not be understood as physical spaces, as a static place within the community, but rather as the environment in which certain activities are carried out and, therefore, create a certain type of discourse.

Figure 2 - Sociodiscursive spaces in the village Buridina
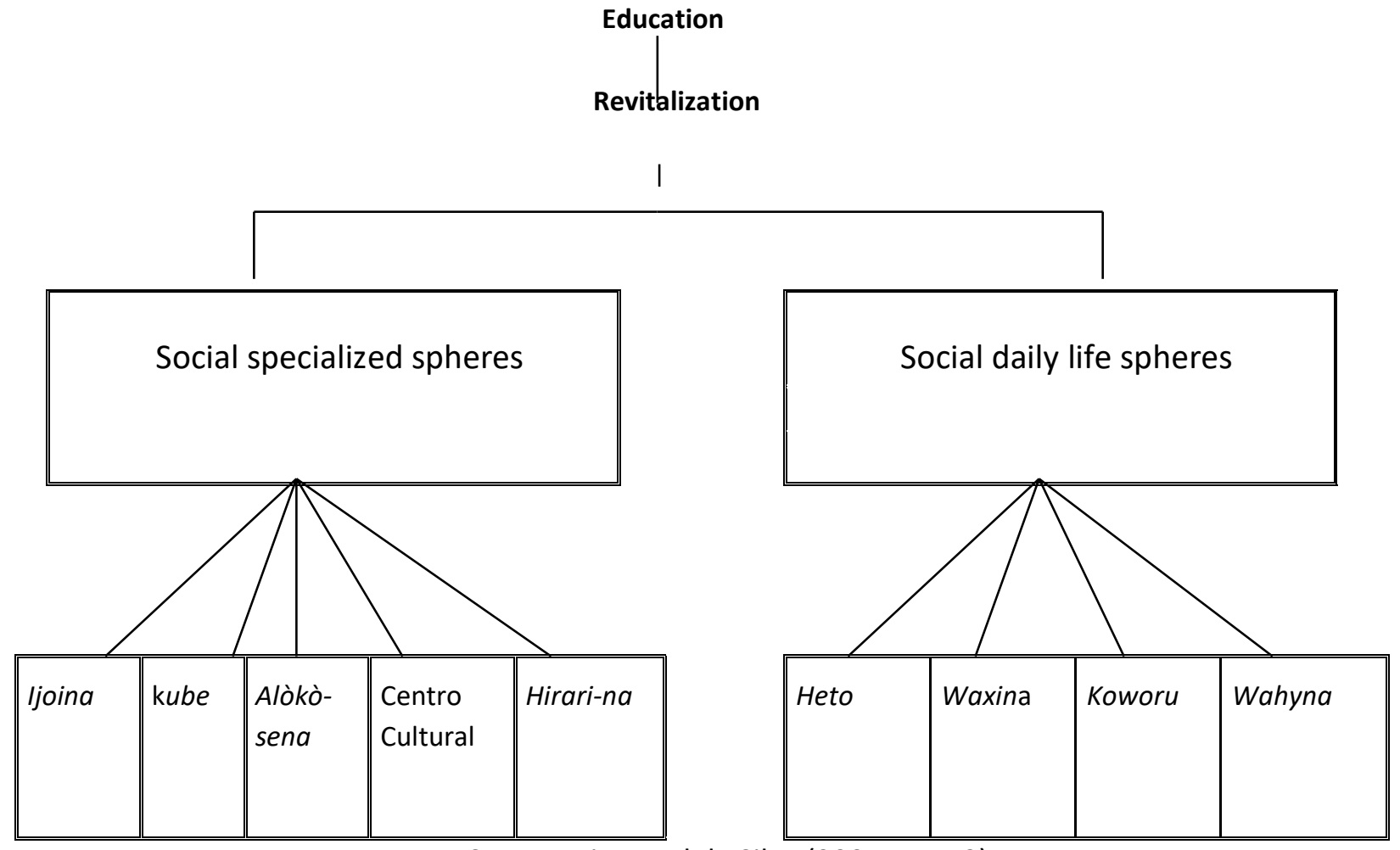

Source: Pimentel da Silva (2001, p. 112).

By means of the (re)creation of these sociodiscursive spaces in Buridina, young people have been experiencing real moments of the Karajá language usage, both inside and outside their community as well as during visits to other Karajá villages. Therefore, the different discourse genres are being produced, sometimes in a specialized sphere, sometimes in daily life sphere, reinforcing cultural bonds which are connected to each sphere and to each type of discourse and human activity.

Listed below are the specialized social spheres of Karajá language usage aforementioned as well as the explanation of each one: 
1. ljoina - it literally means the men's place (ijoi- collective noun of man, -na: locative suffix). ljoina is a strictly male space (that is, a man's place). Women do not participate in this space, and even the paths that give access to ijoina are prohibited to women. In this space, men discuss important community issues, built, and teach how to build handicrafts to young people as well as informing them about their obligations as adults. This space is the centre of the ceremonial life, a place where men are educated.

2. Kube - an outside area in front of the narrators' house - This is the place where myths are narrated by men and women, usually by grandparents or parents.

3. Alòkòsena - place for working - It is any place where women and men work, for example, the place where women gather together on a mat to make handicrafts, or the place where men gather together to work in any kind of activity.

4. Hirarina - it literally means the girls' place (hirari- girl, -na: locative suffix). It is the place of all adult women, young girls and boys not yet initiated through rituals. Women go out from this place to dance with the ijasò (mythological entity) on ritual occasions or they just witness this social activity. Men can participate in the hirarina on special occasions (on ritual occasions, for instance).

Informal spaces:

5. Heto - house, place where they live.

6. Wahyna - place where you fish with an arrow.

7. Riuna - place to hunt.

8. Koworu - plantation, place to grow crops.

Karajá education has particularities in relation to language acquisition that vary according to the gender and age of the children. We mentioned earlier that the Karaja of Buridina have contact with both the Portuguese language and the Karajá language from childhood on. From early ages, girls help their mothers with household chores by playing with dolls, cooking, and learning how to produce miniature karajá dolls. Boys play, make little arrows, paddle canoes, swim, hunt birds, build miniatures of the ijasò house. Both boys and girls play by imitating adults in ritual ceremonies.

In the Karajá language, Iny Rybè, there is phonological variation that depends on gender differences, that is, women have a different way of speaking from men. A man or a woman can only use variants of the speech of the opposite gender when they make comments about a person of that gender. Fortune and Fortune (1975) and Borges (1997, 2002) stress the distinction of female and male speech in Karajá. As Vale affirms (1995 apud BORGES, 2002, p. 7), in "the first verbal interactions with the children, parents establish differentiation in speech according to the rules for each gender". These differences are not restricted to linguistic forms since the Iny society has some female and male social spaces, such as: ijoina - men's place, exclusive space for men to which access is expressly forbidden to women; hirarina - women's place - female space.

The acquisition of Karajá by children at home is guided by parents how to speak according to the speech of each gender. We therefore conclude that the acquisition in the 
family environment is spontaneous (characterized by the informality of the speeches and games) and guided at the same time (because children are always guided to speak according to gender, age and subjects which are exclusive for a certain gender).

\section{Final remarks}

Due to the expansion of spaces for Karajá language usage and, mainly, due to activities that value cultural and intercultural aspects, both social specialized spheres and social daily life spheres find their place in the community of Buridina. As stated by Hamel (1988), language needs to have a social function in the community so that it is used and established as the language of peoples.

The connection between the styles of speech that are produced in the spheres of specialized ideology and those that occur in informal daily life plays a fundamental role in maintaining Karajá language, which we understand here as ethnic language. In accordance with Hamel (1988), when the minority mother tongue fails to solve communicative tasks and to contribute to the cultural, political, economic, social and religious organization of the community, it loses its historical place as a living language, and the community starts to accept more passively one language as a dominant language. In Buridina, the Karajá language has almost lost its place in the lives of the people who speak it. This reality has been gradually changing, and this change characterizes the restoration of functionality of the Karajá language in this village and consequently the attitude of the indigenous people in relation to their language and traditional cultural activities.

The acquisition of Karajá as a second language, in Buridina, occurs both within school contexts as well as in other contexts since the use of that language is connected to all cultural activities belonging to that community. The reconstruction of spaces for Karajá language usage in Buridina is established mainly from the reintegration of traditional cultural activities in this community. The school plays an essential role in this process and restores Karajá language usages in the daily lives of people from the village. Based on informal conversations with the people involved in this process, we realized that most of the respondents believe in the importance of school as a way to rescue their mother tongue both in oral and written forms.

\section{References}

BAKER, Colin. Foundations of bilingual education and bilingualism. 3. ed. Clevedon: Multilingual Matters, 2001.

BORGES, Mônica Veloso. As distinções entre as falas feminina e masculina no Karajá: subsídios ao Projeto de Educação e Cultura Indígena Maurehi. Revista do Museu Antropológico, v. 5/6, n. 1, p. 101-140, 2002.

BRASIL. Presidência da República. Casa Civil. Constituição da República Federativa do Brasil: promulgada em 5 de outubro de 1988. Brasília, 1988. Disponível em: 
<http://www.planalto.gov.br/ccivil_03/Constituicao/Constituicao.htm>. Acesso em: 28 nov. 2015.

CÓRDOVA GASTIABURU, Paula. ¿Cambio o muerte de las lenguas? Reflexiones sobre la diversidad lingüística, social y cultural del Perú. Fondo Editorial de la Universidad Peruana de Ciencias Aplicadas. Lima, 2006.

ELLIS, Rod. The study of second language acquisition. Oxford: Oxford University Press, 1994.

ELLIS, Rod. Second language acquisition. Oxford: Oxford University Press, 1997.

FORTUNES, David; FORTUNE, Gretchen. Karajá men's-women's speech differences with social correlates. Revista IHGB, v. 1, p. 111-124, 1975.

GROSJEAN, François. Life with two languages: an introduction to bilingualism. 11. ed. Cambridge: Harvard University Press, 2001.

HAMEL, Rainer Enrique. La política del lenguaje y el conflicto interétnico: problemas de investigación sociolingüística. In: ORLANDI, Eni Pulcinelli (Org). Política lingüística na América Latina. Campinas: Pontes, 1988. p. 41-73.

KLEIN, Wolfgang. Second language acquisition. Cambrigde: Cambrigde University Press, 1986. https://doi.org/10.1017/CBO9780511815058

KRASHEN, Stephen D. Second Language Acquisition and Second Language Learning. University of Southern California, 2002[1981]. Disponível em: <http://www.sdkrashen.com/sl_Acquisition_and_Learning.pdf>. Acesso em: 22 abr. 2017.

MAHER, Terezinha Machado. Ser professor sendo índio: questões de lingua(gem) e identidade. 1996. 261f. Tese (doutorado) - Universidade Estadual de Campinas, Instituto de Estudos da Linguagem, Campinas, SP.

OLIVEIRA, Caroline Pereira de. Aquisição de língua étnica como segunda língua. 2007. 43f. Monografia (Bacharelado em Linguística) - Universidade Federal de Goiás. Goiânia, 2007.

OLIVEIRA, Caroline Pereira de; PIMENTEL DA SILVA, Maria do Socorro (Org.). Iròdu Rubu. 1. ed. Goiânia: Editora da UFG, 2011. v. 1.

PIMENTEL DA SILVA, Maria do Socorro. Projeto de Educação e Cultura Indígena Maurehi. Universidade Federal de Goiás. Pró-Reitoria de Pesquisa e Pós-Graduação. Goiânia: Faculdade de Letras, 1994.

PIMENTEL DA SILVA, Maria do Socorro. A função social do mito na revitalização cultural da língua Karajá. 2001. 242 f. Tese (Doutorado em Lingüística Aplicada e Estudos da Linguagem) - Pontifícia Universidade Católica de São Paulo, São Paulo.

PIMENTEL DA SILVA, Maria do Socorro (Org). Iny rybé bèdèèryna. Goiânia: Ed. da UCG, 2007.

PORTELA, Cristiane de Assis. Nem ressurgidos, nem emergentes: a resistência histórica dos Karajá de Buridina em Aruanã - GO (1980-2006). 2006. 233 f. Dissertação (Mestrado em História) - Universidade Federal de Goiás. Goiânia, 2006.

ROMAINE, Suzanne. Bilingualism. 2 ed. Oxford: Blackwell, 1995.

SCHÜTZ, Ricardo. Stephen Krashen's theory of second language acquisition. English Made in Brazil. Disponível em: <http://www.sk.com.br/sk-krash.html>. Acesso em: 29 jan. 2016. 
Ethnic Language and Bilingualism:

The Acquisition of Karajá as a Second Language
Caroline Pereira de Oliveira Rogério Vicente Ferreira Vanessa Hagemeyer Burgo

SEKI, L. Notas sobre a História e a situação lingüística dos Povos Indígenas do Alto Xingu. In: SEKI, L. (Org.) Linguística e educação indígena na América Latina. Campinas: Unicamp, 1993, p. 89-117.

Recebido em: 19/04/2020.

Aceito em: 22/09/2020. 